\title{
Diet Effects on Growth, Mortality, RNA: DNA Ratio and Gene Expression of Zebrafish Danio rerio
}

\author{
Md. Golam Rabbane ${ }^{1, *}\left(\mathbb{D},{\text { Md. Yousuf } \text { Ali }^{1}, \text { Md. Al Zahid }^{1} \text {, Jakir Hossain }}^{2}\right.$ \\ ${ }^{1}$ University of Dhaka, Department of Fisheries, Bangladesh. \\ ${ }^{2}$ Sher-e-Bangla Agricultural University, Department of Marine Fisheries and Oceanography, Dhaka-1207, Bangladesh.
}

\section{Article History}

Received Aug 08, 2019

Accepted Jan 31, 2020

First Online Feb 07, 2020

\section{Corresponding Author \\ Tel.: +8801818229810 \\ E-mail: rabbane@du.ac.bd}

\section{Keywords}

Natural diets

Commercial diets

Condition factor

Growth hormone

Gene expression

\begin{abstract}
This study evaluated the effects of different combination of commercial and natural diets (T1: egg yolk, T2: egg yolk+ Artemia, T3: Horlicks, T4: Horlicks+ Artemia, T5: TetraBits, T6: TetraBits+ Artemia, T7: NovoTom, T8: NovoTom+ Artemia) on growth, mortality, RNA: DNA ratio and gene expression of zebrafish for a period of 45 days. Significantly highest length $(2.75 \pm 0.04 \mathrm{~cm})$ and weight $(0.25 \pm 0.10 \mathrm{~g})$ gain were recorded in $\mathrm{T} 2$ treatment. Lowest length gain $(2.00 \pm 0.08 \mathrm{~cm})$ and weight gain $(0.14 \pm 0.12 \mathrm{~g})$ were calculated in T3. Significant highest mortality $(65.00 \pm 8.66 \%)$ was observed in treatment $\mathrm{T7}$ followed by $\mathrm{T} 5$ and $\mathrm{T} 8$ and significant lowest mortality $(20.00 \pm 7.64 \%)$ was recorded in T2. By molecular analysis, Highest RNA: DNA ratio was found (1.01) in T5 followed by T4 (0.95) and lowest was found in T1 (0.77). Interestingly, a similar result was observed for gh1 (Growth hormone 1) gene expression. Highest gene expression was found in T5 followed by T4 and lowest in T2. Significant down regulation was observed in T2 for gh1 gene. Finally, the study would suggest that zebrafish can be fed with egg yolk+Artemia for better growth performance. The findings could provide a significant contribution to the field of global zebrafish as well as aquaculture research.
\end{abstract}

\section{Introduction}

Zebrafish (Danio rerio) is a small freshwater fish under the order of Cypriniformes. It is found in freshwater habitats like pond, river, beel, canal, paddy field of south Asian countries like Bangladesh, Nepal, India, etc (Engeszer, Patterson, Rao, \& Parichy, 2007). It has become one of the significant models over the world in the field of scientific research. Right now, this fish has also been utilized widely as model fish in many aquaculture research (Ulloa, Iturra, Neira, \& Araneda, 2011; Ribas \& Piferrer, 2014) particularly improving husbandry and survival, immune response, nutrition and growth of commercially important fishes over the world (Ulloa, Pena, Lizama, Araneda, Iturra, Neira \& Medrano,
2013). Moreover, zebrafish is also using as a model fish for nutritional genomic studies also called nutrigenomics where expression of certain genes is studied (Drew, Rodnick, Settles, Wacyk, Churchill, Powell \& Robison, 2008; Robison, Drew, Murdoch, Powell, Rodnick, Settles \& Lewis, 2008).

Over the world in a zebrafish laboratory as well as aquaculture farm and hatchery, usually different kinds of commercial and natural diets are supplied like Tetra bits (TetraBits ${ }^{\circledR}$ Complete, Tetra GmbH, Germany), JBL Novotom Artemia, etc. Live Artemia nauplii are also significantly used in thousands of zebrafish laboratory worldwide for the consumption of both zebrafish larvae and adult. Recently, some works have been performed on effects of feeds on growth and reproduction of adult 
zebrafish with little attention given to larvae to young stages (Gonzales, 2012; Rabbane \& Rahman, 2017)

The analysis of RNA: DNA ratio is used to study the healthy condition of different aquatic organisms and animals like planktons either phytoplankton (Berdalet \& Dortch, 1991) or zooplankton (Gorokhova \& Kyle, 2002; Gorokhova, 2003), fishes in different stages like larval (Clemmesen, 1994; Pepin, Evans, \& Shears, 1999; Gwak, Tanaka, Tominaga, Tsusaki, \& Tanaka, 2003) and adult stages (Smith \& Buckley, 2003). This approach has demonstrated especially appropriate for investigations of larval fish, which show conceivably fast, almost ceaseless development of absolutely somatic tissues (i.e., energy accessible for larval fish development isn't directed to shedding or gonadal tissue). The quality and quantity of RNA and DNA and its sources of variation in a fish especially in larval fish depends on some factors like the ontogenetic stages, effects of temperature and methodology (Foley, Bradley, \& Hook, 2016).

In many nutritional studies, the performance of feed is analyzed through the genetical view. There are many genes (i.e. insulin-like growth factor 1 and 2, growth hormone gene, etc) those are involved in cell division, cell cycle process, skeletal myogenesis of tissue (Moriyama, Ayson, \& Kawauchi, 2000). Over the last 20 years, significant numbers of studies have been performed to analyze the relationship between the effects of diets and its ingredient with gene expression.

Although pertinent kinds of literature are available on zebrafish as model animal in research (Ulloa et al., 2011; Lawrence, 2007; Lieschke \& Currie, 2007) but very little work has been completed to have a look at the effects of diets on the nutrigenomics of fish. So, this work has been designed for zebrafish as an aquaculture model. Therefore, the study was conducted to determine effects of diet on larval growth performance, mortality, RNA: DNA ratio and growth specific gene expression of zebrafish Danio rerio fed with different types of feeds and their combination.

\section{Material and Methods}

For this experiment, several couples of wild and adult zebrafish were collected from zebrafish facility of Department of Fisheries, University of Dhaka, Bangladesh. In the evening, adult male and female zebrafish were kept in a $1 \mathrm{~L}$ capacity breeding tank using a separator in

the tank to separate male from female. In the early morning, zebrafish released eggs and fertilized eggs were collected and stored in Petri dish for further development. After 2 days the eggs were hatched and the hatchlings were collected and reared in petri-dish for first 5 days without any feeding. After that, these 5 days larvae were transferred to the experimental tanks and experimental diets were supplied to the respective aquaria except Artemia. The experiment was conducted in 24 experimental aquaria (5L capacity) at the Department of Fisheries, University of Dhaka. All those aquaria were randomly placed in a steel made rack under room temperature. The study was undertaken for a period of 45 days. This was a one factorial study with eight feed combination in triplicates. All aquaria were filled in with tap water and labeled according to experimental design. Twenty fish larvae were stocked in each aquarium. Aeration (Sobo aquarium air pump SB348A) was given by electricity for 24 hours during the experimental period. All aquaria were held clean to provide a hygienic condition. Water quality parameters such as $\mathrm{pH}$, temperature, dissolved oxygen concentration and total dissolved solids (TDS) were checked and recorded by using multiparameter kit (Model: HI9828 Multiparameter, HANNA instruments, Woonsocket. RI, USA). 75\% water was exchanged with new water at every one-day interval from each aquarium.

The experimental aquaria were monitored every day to observe the behavior of fishes. The experimental fish were fed at the satiation level and three times a day with their respective experimental diets in different aquaria. Eight feed combinations were used in this experiment such as T1: Egg yolk, T2: Egg yolk + Artemia nauplii, T3: Horlicks, T4: Horlicks + Artemia nauplii, T5: TetraBits T6: TetraBits+ Artemia nauplii, T7: Novotom, T8: Novotom + Artemia. nauplii. GSL (Great Salt Lake) Artemia cyst was purchased from local market and decapsulated it at $30 \mathrm{ppt}$ saline water and served to the respective fish of 15 days post fertilization because first feeding zebrafish are not capable to eat decapsulated Artemia. But other diets were supplied from the first feeding stage of fish. Here, according to United States Department Agriculture (USDA), chicken egg yolk contains about $16 \%$ protein, $32-35 \%$ lipid and $48 \%$ moisture. Artemia nauplii has $41-47 \%$ protein, $21-23 \%$ lipid, $11 \%$ carbohydrate and $10 \%$ ash. According to manufacturer's information: Horlicks (India) contains $22 \%$ protein, $3 \%$ lipid and $0 \%$ carbohydrate; TetraBits fish feed (Germany) contains protein $47.5 \%$, oil $6.5 \%$, fiber $2.0 \%$, ash $10.5 \%$, moisture $6.0 \%$; JBL Novotom Artemia fish feed (JBL, Germany) has crude protein 43\%, crude fat $8.5 \%$, crude fiber $1.9 \%$ and crude ash $9 \%$.

After 45 days of rearing, the fish were sampled for the measurement of growth parameter and molecular analysis separately. About $30 \%$ of fishes were randomly sampled from 24 experimental aquaria to measure the total length $(\mathrm{cm})$, standard length $(\mathrm{cm})$ and weight $(\mathrm{g})$.

The following formulae were used in calculating mortality rate (\%), weight gain(gm), length gain $(\mathrm{cm})$, and condition factor. weight

Mortality rate $=\frac{\text { Number of fish died }}{\text { Number of fish stocked }} \times 100$

Weight gain $(g)=$ Mean final weight - Mean initial

Length gain $(\mathrm{cm})=$ Mean final length $(\mathrm{cm})-$ Mean initial length $(\mathrm{cm})$ 
$K=\left(W / L^{3}\right) \times 100$ Where, $K=$ Condition factor; $W=$ Body weight in grams; $L=$ Body length in centimeter.

For the determination of RNA: DNA ratio, Wizard $^{\circledR}$ Genomic DNA purification kit (Promega, USA) was used with slight modifications for the purpose of nucleic acid extraction. RNAse was not used in the procedure. At first $10 \mathrm{mg}$ of fresh chilled fish, tissue was ground with mortar pestle and transferred it in a $2 \mathrm{ml}$ tube. Then $600 \mu \mathrm{l}$ of chilled Nuclei Lysis Solution was added in the tube homogenize for 10 seconds. The tissue sample was then incubated at $65^{\circ} \mathrm{C}$ for 20 minutes in a water bath. After incubation, 200 $\mu$ l of Protein Precipitation Solution was added in the sample and chilled on ice for 5 minutes. The sample was then centrifuged at $14000 \mathrm{rpm}$ for 4 minutes. After centrifugation, the supernatant was transferred to a fresh tube containing $600 \mu \mathrm{l}$ of room temperature isopropanol. The sample into the tube was mixed by gently inversion of the tube. The sample was then centrifuged at $14000 \mathrm{rpm}$ for 1 minute. Then the supernatant was removed from the sample and $600 \mu \mathrm{l}$ of room temperature $70 \%$ ethanol was added and mixed. Again, the sample was centrifuged at $14000 \mathrm{rpm}$ for 1 minute. The ethanol was aspirated from the sample and the pellet was allowed to dry $15 \mathrm{~min}$. The pellet was rehydrated in $100 \mu$ l of DNA Rehydration Solution for overnight at $4^{\circ} \mathrm{C}$. Finally, the quantity of RNA and DNA was measured by using the Nanodrop 2000 Spectrophotometer with absorbance level at $260 / 280 \mathrm{~nm}$. After calibration, $1 \mu \mathrm{l}$ of each sample was used for measurement of RNA and DNA.

For gene expression analysis, several procedures such as total RNA extraction, RNA quantification, cDNA synthesis, primer selection, qPCR analysis, real time analysis were performed carefully. Maxwell ${ }^{\circledR}$ RSC simply RNA kit and Maxwell ${ }^{\circledR}$ RSC instrument (Promega, USA) were used for the extraction of total RNA from the samples using manufactures' protocol. For RNA extraction, at first $20 \mathrm{mg}$ fresh tissue sample was added in a $1.5 \mathrm{ml}$ micro centrifuge tube which contains $200 \mu \mathrm{l}$ lysis buffer and homogenized. Then the homogenized sample was incubated at ice for $10 \mathrm{~min}$. The total sample was transferred to new $1.5 \mathrm{ml}$ tube containing $500 \mu \mathrm{l}$ RNA Dilution Buffer. Then, $50 \mu$ l Clearing Agent was added to the sample and vortexed for 30 seconds. After vortexing, the sample was incubated at $70^{\circ} \mathrm{C}$ for $3 \mathrm{~min}$. Vortexing was done again for 30 seconds and incubated the sample at room temperature for $5 \mathrm{~min}$. The total sample was then transferred to a column and centrifuged at $12000 \mathrm{rpm}$ for $2 \mathrm{~min}$. Then, it was transferred in a Maxwell-16 Cartridge. Moreover, $300 \mu \mathrm{l}$ Elution buffer was taken in the elution tube. Finally, Maxwell-16 RNA extraction protocol was run for total RNA extraction. After that, mRNA was quantified by Nano-Drop 2000 (Thermo) spectrophotometer. Then cDNA was synthesized using GoScript ${ }^{\mathrm{TM}}$ Reverse Transcription System (Promega, USA). For cDNA Synthesis, several steps were followed to convert up to $5 \mu \mathrm{g}$ of total RNA or up to 500ng of poly (A) RNA into firststrand cDNA. At first, water was used in PCR tube to make total volume of $5 \mu \mathrm{L}$. Then, the volume was heated in a $70^{\circ} \mathrm{C}$ heat block for 5 minutes. Immediately it was chilled in ice water for at least 5 minutes. The solution was centrifuged 10 seconds in a micro centrifuge. Then the solution was stored on ice until reverse transcription mix (GoScript Reaction Buffer: $4.0 \mu \mathrm{l}, \mathrm{MgCl}_{2}$ : 3.0 $\mu \mathrm{l}$, dNTP mix: $1.0 \mu l$, Reverse Transcriptase: $1.0 \mu \mathrm{l}$, Nuclease-Free Water: $6.0 \mu \mathrm{l}$ ) was added. $15 \mu \mathrm{l}$ of reverse transcription mix was combined with $5 \mu$ l of RNA and primer mix. The mix was annealed in a heat block at $25^{\circ} \mathrm{C}$ for 5 minutes. The mix was extended in a heat block at $42^{\circ} \mathrm{C}$ for up to one hour. Reactions can be stopped at this point for the analysis of the cDNA or might be frozen for long-term storage. Before proceeding with $\mathrm{qPCR}$, the reverse transcriptase was inactivated in a heat block at $70^{\circ} \mathrm{C}$ for 15 minutes. Finally, quantitative real time PCR was performed using qTOWER ${ }^{3}$ real time PCR thermal cycler (Analytic Jena, Germany). GoTaq ${ }^{\circledR}$ qPCR master mix (Promega, USA) and fluorescent dye (Syber green) were used. In qPCR, two primes were used, house-keeping gene primer (ef1a) and Growth hormone gene primer (gh1). The sequences of the selected primers are presented in Table 1. For qPCR analysis, real-time PCR instrument and related equipment, nuclease-free pipettes dedicated to pre-amplification work, cDNA template, qPCR primers were used. The final reaction volume in this protocol was $20 \mu \mathrm{L}$. The volumes given here may be scaled for larger or smaller reaction volumes. cDNA template added should not exceed $20 \%$ $(v / v)$ of the qPCR reaction volume, unless diluted. The appropriate volume of the reaction mixture was added to each PCR tube or well of an optical-grade PCR plate. The cDNA template (or water for the no-template control reactions) was added to the appropriate wells of the reaction plate. The tubes or optical plate was sealed and centrifuged briefly to collect the contents of the wells at the bottom. The program of the qPCR cycler was $95^{\circ} \mathrm{C}$ for 3 minutes followed by 45 cycles at $95^{\circ} \mathrm{C}$ for 15

Table 1. Primers used for $\mathrm{qPCR}$ analysis

\begin{tabular}{llll}
\hline Primers & Orientation & Sequence $\left(\mathbf{5}^{\prime}--->\mathbf{3}^{\prime}\right)$ & Accession Number \\
\hline ef1a-F & Sense & GAC AAG AGA ACC ATC GAG & NM_131263 \\
ef1a-R & Antisense & CCT CAA ACT CAC CGA CAC & - \\
gh1-F & Sense & ATC AGC GTG CTC ATC AAG G & NM_001020492.2 \\
gh1-R & antisense & TCC ACC TTG TGC ATG TCC T & - \\
\hline
\end{tabular}


seconds and $60^{\circ} \mathrm{C}$ for 31 seconds. Dissociation curves and threshold cycles (Ct) were automatically calculated by qPCRsoft 3.2. Expression level in qPCR was calculated by Delta Ct method.

In this experiment, the observed data were analyzed using different software. Excel software was used for graphical presentation with error bars. Growth performances, condition factor, and mortality rate were analyzed by one-way ANOVA and Tukey's post-hoc test using SPSS software. The results (Ct value) of qPCR cycler obtained from qPCRsoft 3.2 were analyzed using the Relative Expression Software Tool (REST) (Pfaffl, Horgan, \& Dempfle, 2002).

\section{Results and Discussion}

The water quality parameters of day 25 and day 45 are presented in Table 2. Highest DO (Dissolve Oxygen) $(2.83 \pm .76 \mathrm{ppm})$ was found in treatment T5 (Tetra bits) of the first measurement at 25 days and the highest DO $(2.79 \pm .86 \mathrm{ppm})$ was found in treatment T7 (Novotom) at 40 days of the culture period. Lowest $\mathrm{DO}(0.86 \pm .11 \mathrm{ppm})$ was found in treatment T4 (Horlicks) at 25 days of culture and at 40 days it was T8 (Novotom + Artemia).

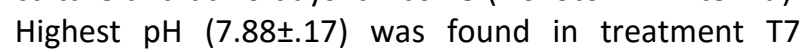
(Novotom) and lowest (7.49 .03 ) was in treatment T8 (Novotom +Artemia) at 25 days of measurement. At 40 days of the culture period, lowest $\mathrm{pH}(7.69 \pm 0.27)$ was found in treatment T8 and highest $(8.06 \pm 0.09)$ was recorded in treatment $\mathrm{T} 7$. Highest Temperature $\left(29.20 \pm 0.13^{\circ} \mathrm{C}\right)$ was found in treatment $\mathrm{T} 1$ (Egg Yolk) and lowest $\left(28.70 \pm 0.49^{\circ} \mathrm{C}\right)$ was in treatment $\mathrm{T} 5$ (Tetrabits) at 25 days and 40 days of the culture period. Oxidation Reduction Potential (ORP) was found largest (91.73 \pm .34 $\mathrm{mV}$ ) in treatment T4 (Horlicks + Artemia) and less $(33.76 \pm 2.21 \mathrm{mV})$ in treatment T5 (Tetra bits) at 25 days (Table 2). At 40 days highest ORP $(57.3 \pm 2.72 \mathrm{mV})$ was in treatment T4 and lowest $(40.67 \pm 2.19 \mathrm{mV})$ was in treatment T7. Highest $(1030.43 \pm 0.03 \mathrm{~ms} / \mathrm{cm})$ EC was found in treatment T4 (Horlicks+Artemia) and lowest
$(1030.13 \pm 0.03 \mathrm{~ms} / \mathrm{cm})$ was in treatment T7 (Novotom + Artemia) at 25 days and 40 days of measurement. Highest TDS (ppm) $(237.55 \pm 0.88 \mathrm{ppm})$ was found in treatment $\mathrm{T} 5$ and lowest (ppm) $(229.33 \pm 1.33 \mathrm{ppm})$ was in $\mathrm{T7}$ at 25 days. But at 40 days the highest TDS $(237.67 \pm 0.88 \mathrm{ppm})$ was found in treatment $\mathrm{T} 7$ and lowest (228.66 $\pm 0.33 \mathrm{ppm})$ was found in T2.

Water quality parameters play a significant role in a fish culture system. In this experiment, water quality parameter like dissolved oxygen (DO), $\mathrm{pH}$, oxidation reduction potentials (ORP), electrical conductivity (EC) and TDS were measured. Most of the parameters were in the acceptable range of fish culture. Though the appropriate range of temperature for zebrafish is 24 $30^{\circ} \mathrm{C}$ (Matthews, Trevarrow, \& Matthews, 2002), the maintenance temperature at laboratory condition is $28.5^{\circ} \mathrm{C}$ (Westerfield, 1995). Zebrafish is a hardy fish and it can tolerate a wide range of temperature $\left(12-40^{\circ} \mathrm{C}\right)$, especially adult zebrafish. The TDS level was in acceptable range in our study, because the tolerable limit of TDS for the most aquatic animal including fish is $1000 \mathrm{mg} / \mathrm{l}$ (Boyd, 1999). DO is the most significant water quality parameters in a culture system, because any fluctuation from the standard level of DO may cause higher fish mortalities (Timmons, Ebeling, Wheaton, Summerelt, \& Vinci, 2002). Popma and Masser (1999) reported that zebrafish, a tropical fish species, can tolerate lower levels of dissolved oxygen; that's why they can survive in a poor oxygen laden habitat in nature. Timmons et al. (2002) recommended pH 6 to 9.5 as the tolerable range for the most freshwater fish. That's why the better condition $\mathrm{pH}$ range maintained for the most freshwater fish is 7-8. So, the $\mathrm{pH}$ of culture tanks of this study was in better condition.

Growth performance in terms of length gain and weight gain of cultured fish is presented in Table 3 . Significantly highest length gain $(2.75 \pm 0.04 \mathrm{~cm})$ was found in $\mathrm{T} 2$ (egg yolk + artemia) followed by T6, T8, and T4. Lowest length gain $(2.00 \pm 0.08 \mathrm{~cm})$ was found in T3 (Horlicks). Similar results were recorded for weight gain

Table 2. Water quality parameters in different treatments at 25 days and 40 days of culture period

\begin{tabular}{lccccccccc}
\hline & & T1 & T2 & T3 & T4 & T5 & T6 & T7 & T8 \\
\hline \multirow{2}{*}{ DO $(\mathrm{ppm})$} & 25d & $2.43 \pm .16$ & $1.29 \pm .19$ & $1.80 \pm .11$ & $0.86 \pm .11$ & $2.83 \pm .76$ & $1.43 \pm .51$ & $2.79 \pm .86$ & $2.02 \pm .29$ \\
& 45d & $3.73 \pm .07$ & $3.25 \pm .29$ & $3.10 \pm .31$ & $2.38 \pm .50$ & $4.24 \pm .67$ & $2.77 \pm .69$ & $5.04 \pm .32$ & $2.02 \pm .17$ \\
PH & 25d & $7.62 \pm .03$ & $7.63 \pm .02$ & $7.62 \pm .01$ & $7.75 \pm .05$ & $7.80 \pm .29$ & $7.64 \pm .40$ & $7.88 \pm .17$ & $7.49 \pm .03$ \\
Temperature & 45d & $7.79 \pm .14$ & $7.75 \pm .07$ & $7.77 \pm .05$ & $7.79 \pm .04$ & $7.86 \pm .09$ & $7.83 \pm .12$ & $8.06 \pm .09$ & $7.69 \pm .27$ \\
$\left({ }^{\circ} \mathrm{C}\right)$ & 25d & $29.20 \pm .13$ & $29.00 \pm .05$ & $29.10 \pm .03$ & $29.09 \pm .10$ & $28.70 \pm .49$ & $28.77 \pm .10$ & $28.72 \pm .06$ & $28.77 \pm .04$ \\
ORP $(\mathrm{mV})$ & 45d & $29.33 \pm .04$ & $29.27 \pm .07$ & $29.1 \pm .05$ & $29.09 \pm .11$ & $28.7 \pm .05$ & $28.77 \pm .11$ & $28.73 \pm .06$ & $28.78 \pm .47$ \\
& 25d & $65.93 \pm .61$ & $83.53 \pm .59$ & $67.93 \pm 1.21$ & $91.73 \pm .34$ & $33.76 \pm 2.21$ & $87.83 \pm 2.00$ & $58.13 \pm 1.03$ & $78.90 \pm 4.16$ \\
EC $(\mathrm{ms} / \mathrm{cm})$ & 25d & $45.83 \pm 1.98$ & $53.87 \pm 3.27$ & $51.27 \pm 5.27$ & $57.3 \pm 2.72$ & $42.67 \pm 3.71$ & $49.87 \pm 7.14$ & $40.67 \pm 2.19$ & $47.23 \pm 3.83$ \\
& 25d & $1030.2 \pm .00$ & $1030.4 \pm .33$ & $1030.4 \pm .00$ & $1030.4 \pm .03$ & $1030.2 \pm .10$ & $1030.3 \pm .03$ & $1030.1 \pm .03$ & $1030.3 \pm .06$ \\
TDS $(\mathrm{ppm})$ & 25d & $233.3 \pm 1.20$ & $236.7 \pm 0.33$ & $228.7 \pm 0.33$ & $234.0 \pm 1.15$ & $237.6 \pm 0.88$ & $234.7 \pm 3.38$ & $229.3 \pm 1.33$ & $234.0 \pm 0.88$ \\
& 45d & $233.3 \pm 1.20$ & $228.7 \pm 0.33$ & $236.7 \pm 0.33$ & $235 \pm 6.00$ & $234 \pm 1.15$ & $229.3 \pm 1.33$ & $237.7 \pm 0.88$ & $234.7 \pm 3.38$ \\
\hline
\end{tabular}


Table 3. Growth performances (mean \pm SEM) of Danio rerio fed different diets

\begin{tabular}{lcc}
\hline \multirow{2}{*}{ Treatments } & \multicolumn{2}{c}{ Variables } \\
\cline { 2 - 3 } & Length Gain $(\mathbf{c m})$ & Weight Gain (g) \\
\hline T1 & $2.32 \pm 0.12_{\mathrm{abc}}$ & $0.16 \pm 0.02_{\mathrm{ab}}$ \\
T2 & $2.75 \pm 0.04_{\mathrm{d}}$ & $0.25 \pm 0.10_{\mathrm{b}}$ \\
T3 & $2.00 \pm 0.08 \mathrm{a}$ & $0.14 \pm 0.12_{\mathrm{a}}$ \\
T4 & $2.37 \pm 0.09_{\mathrm{bc}}$ & $0.19 \pm 0.12_{\mathrm{ab}}$ \\
T5 & $2.11 \pm 0.05_{\mathrm{ab}}$ & $0.15 \pm 0.08_{\mathrm{a}}$ \\
T6 & $2.55 \pm 0.10_{\mathrm{cd}}$ & $0.21 \pm 0.03_{\mathrm{ab}}$ \\
T7 & $2.23 \pm 0.05_{\mathrm{abc}}$ & $0.17 \pm 0.01_{\mathrm{ab}}$ \\
T8 & $2.47 \pm 0.07_{\mathrm{bcd}}$ & $0.18 \pm 0.16_{\mathrm{ab}}$ \\
\hline
\end{tabular}

Mean with different subscript letters denote significant differences for growth parameters.

(Table 3). Significantly highest weight gain $(0.25 \pm 0.10 \mathrm{~g})$ was found in T2 when compared with T3 and T5. But there was no significant difference in weight gain among T1. T4, T6, T7, and T8. Lowest weight gain $(0.14 \pm 0.12 \mathrm{~g})$ was observed in T3 where fish were fed with Horlicks.

Feed quality, quantity, composition, ingredient size, and feeding frequency are the most important factors that control the growth, survival and gene expression of Danio rerio (Panserat \& Kaushik, 2010 and Gonzales, 2012). Kaushnik, Georga, and Koumoundouros (2011) conducted a study on the feeding habit of zebrafish larvae with formulated feed to formulate a standard diet. In our present study, the length gain was $2-2.75 \mathrm{~cm}$ in 45 days feeding different feeds. Carvalho, Araujo, and Santos (2006) found the best overall performance ( $14.3 \mathrm{~mm}$ standard length and $46.1 \mathrm{mg}$ wet weight) of zebrafish larvae fed Artemia nauplii among four different diets (artemia nauplii, a commercial, a purified and a practical diet). However, Gonzales (2012) recorded that there is no effect of a particular feed on zebrafish growth. But a study was conducted by Rabbane and Rahman (2017) and observed a higher growth rate of goldfish fed TetraBits commercial feed. So, the result did not match with their result may be due to the different life stages of fish.

The result of the condition factor of the cultured fish for different treatments is shown in figure 1 . There was no significant condition factor difference of fish among T1, T6, and T8 treatments. But significantly maximum condition factor was calculated in T7

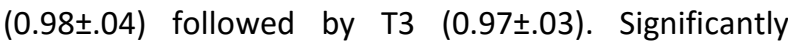
minimum condition factor was calculated in T4 $(0.77 \pm .03)$ fish. Condition factor is an index of length and weight of fish which is used to compare the growth and fitness of fish. Condition factor is also used as an index to compare the growth and well-being of fish based on the principle that the heavier fish of a given length is in better condition. Rahman, Bhadra, Begum, and Hussain (1997) reported the values of condition factor of catfish fed different supplemental feeds between 0.81 and 0.87 .

The mortality rate (\%) of different treatments for 45 days of culture is presented in figure 2 . Significantly highest mortality rate $(65.00 \pm 8.66 \%)$ was found in treatment T8 followed by T5 and T8. Significantly lowest mortality rate $(20.00 \pm 7.64 \%)$ was recorded in $\mathrm{T} 2$ that was fed with Egg Yolk + Artemia. The mortality rate of zebrafish in a very crowded condition is low because zebrafish is very hardy fish by nature. Gonzales (2012) found the mortality rate for zebrafish as $0-16 \%$ which is much lower than our present study. Water quality parameters can affect the survival rate, that's why we found higher mortality rates among treatments. In this study, we found higher mortality in all treatments. This was because we had started our experiment from the larvae stage and normally mortality is always higher in the larvae stage for all fishes.

Additionally, quantitative nucleic acid analysis is considered as an effective way of fish growth rate measurement. The study also confirmed the comparison of different diets on growth performance regarding RNA: DNA ratio measurement (Figure 3). Highest RNA: DNA ratio was calculated in treatment $\mathrm{T} 5$ followed by $\mathrm{T} 4$ and the lowest ratio was found in treatment $\mathrm{T} 1$ followed by T2. Graphical view of RNA: DNA ratio is presented in figure 3. For the measurement of fish growth rate, quantitative nucleic acid analysis can be an effective tool. The increase in growth of somatic tissue can be due to the increase of the level of RNA in tissues, whereas DNA remains constant in somatic tissues (Regnault \& Luquet, 1974). Amount of RNA is also been considered as the indicator of nutritional status and growth of fish (Bergeron, 1997). Akhtar, Pal, Sahu, Ciji, and Gupta (2012); Zehra and Khan (2013); Smith and Buckley (2003) suggested the RNA: DNA as an index of growth of fish species Labeo rohita, Catla catla, and Gadus morhua; respectively.

Gene expression depends on feeding habit and feed type. In order to evaluate the effects of diets on gene expression, relative gene expression of growth hormone was observed through real time PCR (Figure 4). Highest expression ratio (1.039) was measured in T5 followed by T1 and T4 where the lowest (0.863) was recorded in T2 followed by T3. Significantly down regulated gene expression was observed in T2 (Figure 4). T7 was used as a reference.

There are many factors that are responsible for gene up or down regulation. Feed ingredient is one of them that controls growth specific gene expression (Panserat \& Kaushik, 2010). However, in our 
Condition factor (k)

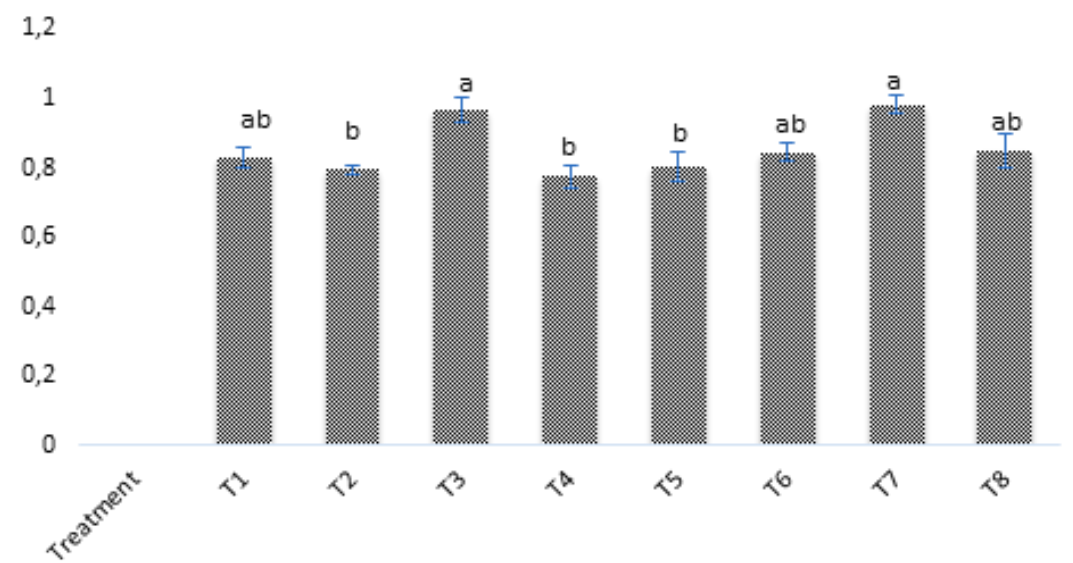

Figure 1. Condition factor of different treatments. Data were recorded as mean $\pm S E M$. Data were analyzed by using one-way ANOVA followed by post-hoc comparison with tukeys test; significance was taken at $\mathrm{P}<0.05$. Bars with different letters denote significant difference in condition factor.

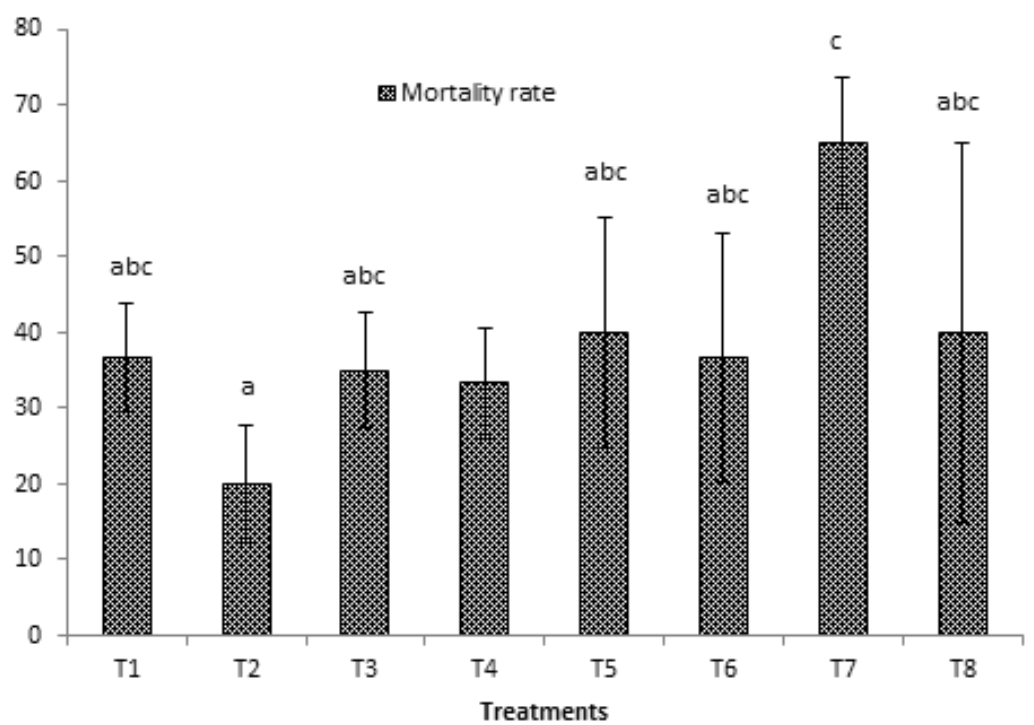

Figure 2. Mortality rate (\%) of different treatments. Data were recorded as mean $\pm S E M$. Data were analyzed by using one-way ANOVA followed by post-hoc comparison with LSD test; significance was taken at $\mathrm{P}<0.05$. Bars with different letters denote significant difference in mortality rate.

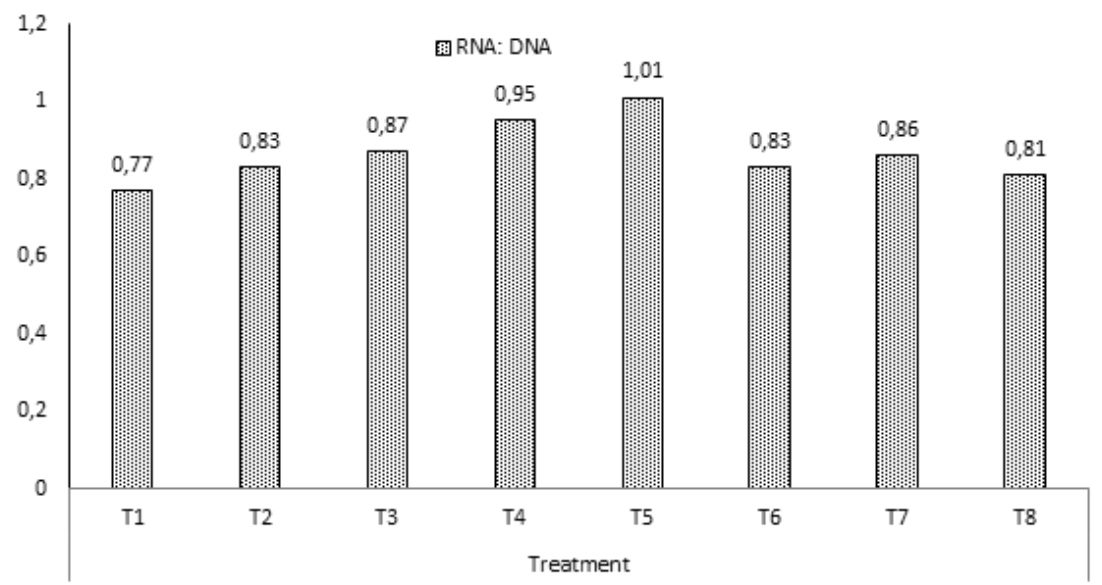

Figure 3. RNA: DNA ratio of fish in different treatments. Data were recorded as mean. 


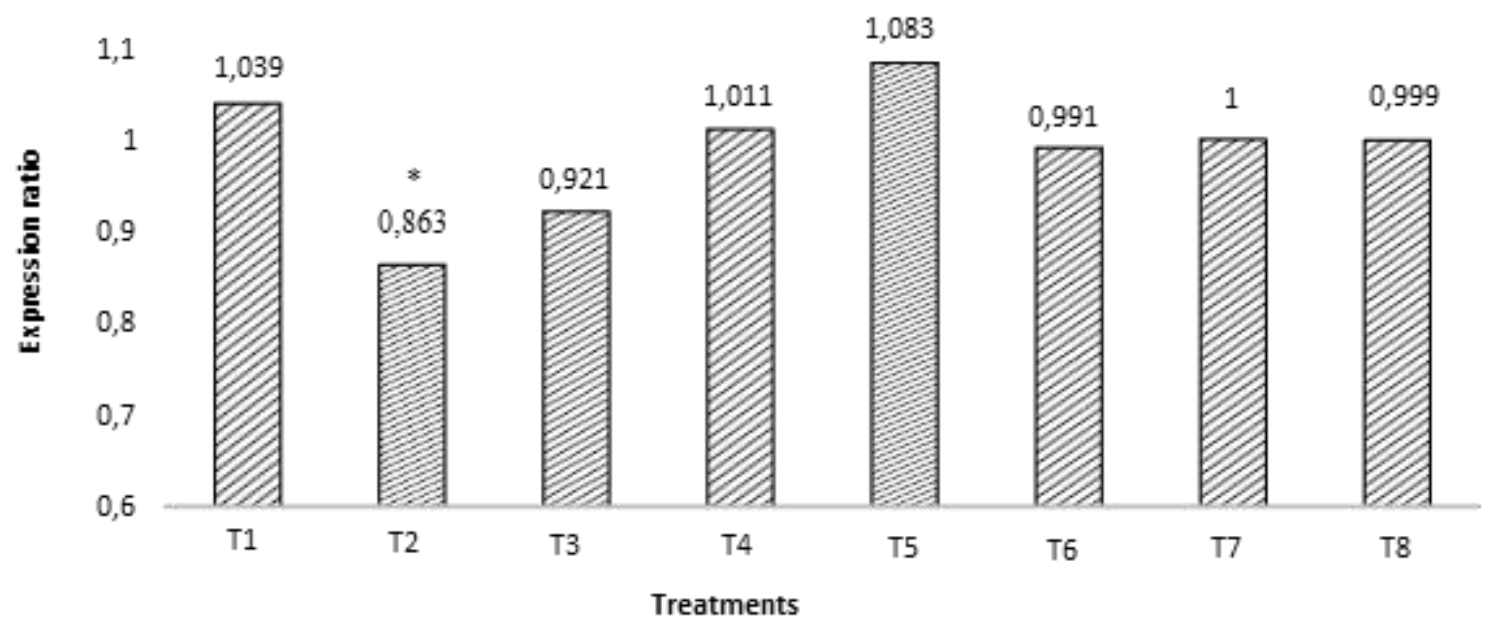

Figure 4. Relative gene expression ratio of different treatments. Data were analyzed using REST software. Bar with star indicates significant down regulation.

experiment, up regulation was found in fish fed commercial diet Tetrabits containing a high amount of protein 47.5\%. Yang, Chan, Lin, and Chen (1997) suggested that all types of salmonid fish contain gh1 and gh2 genes and their expression patterns are different in different life stages and sexes. So, it is very difficult to explain the reason of up and down regulation of growth specific gene. $\mathrm{GH}$, secreted in the adenohypophysis and under hypothalamic control, is involved in the regulation of somatic growth through the introduction of IGF- I (Bjornsson, 1997; Chen, Marsh, Shamblott, Chan, Tang, Cheng \& Yang, 1994). Previous studies have exposed that GH excites the synthesis and discharge of liver IGFI mediating the physiological action of GH (Reinecke, Bjornsson, Dickhoff, McCormick, Navarro, Power \& Gutierrez, 2005), and in turn, IGF-I specifically prevents $\mathrm{GH}$ gene transcription and exudation via a negative feedback mechanism. In addition, the wide tissue distribution of IGF-I producing cells (Reinecke et al., 2005) and IGF-I receptor (IGF-IR) (Radaelli, Domeneghini, Arrighi, Bosi, Patruno, \& Funkenstein, 2003), together with the extensive tissue distribution of GH-receptors (Perez-Sanchez, Calduch-Giner, Mingarro, Celis, Gomez-Requeni, Saera-Vila \& Valdivia, 2002), provides clear data on how GH mediates its actions at cellular level (Reinecke et al., 2005). GH also depends on food habits. In respect of Danio rerio GH was found upregulated in fishes that were fed tetra bits and Horlicks + Artemia. Down- regulated was found in fishes that were fed egg+ Artemia. Gluconeogenic enzyme gene expression is decreased by dietary carbohydrates in common carp (Cyprinus carpio) and gilthead seabream (Sparus aurata) (Panserat, Plagnes-Juan, \& Kaushik, 2001). A comparable proportion of genes were found to be higher or declined in the same course by domestication or $\mathrm{GH}$ transgenesis relative to wild-type, suggesting that changes in specific mRNA are not being strongly inclined by a global regulation of mRNA levels (mRNA: rRNA ratios). Therefore, for these domesticated and $\mathrm{GH}$ transgenic strains with a common phenotype, it seems that many of the same genes are complicated and are adapted in parallel ways by both types of genetic alteration from wild-type (Devlin, Biagi, \& Yesaki, 2004).

\section{Conclusion}

This study concluded that egg yolk+Artemia could be used for better growth of zebrafish in laboratory condition. So, the results of the current study will be helpful to know the effects of diets on growth performance, mortality, gene expression. But the duration of the experiment was 45 days that was not enough time for getting more precise knowledge about gene expression. In upcoming research, it can be conducted with further populations, more samples and individuals and more genes to be explained in the research to make certain explanations about effects of different combined diets on the genetic construction of other species.

\section{Acknowledgment}

Authors are grateful to the University Grant Commission, Government of the People's Republic of Bangladesh for their financial support to conduct this research.

\section{References}

Akhtar, M.S., Pal, A.K., Sahu, N.P., Ciji, A., \& Gupta, S.K. (2012). Effects of dietary pyridoxine on growth and biochemical responses of Labeo rohita fingerlings exposed to endosulfan. Pesticide biochemistry and physiology, 103(1), 23-30.

https://doi.org/10.1016/j.pestbp.2012.02.004 
Berdalet, E., \& Dortch, Q. (1991). New double staining technique for the RNA and DNA measurement in marine phytoplankton. Marine Ecology Progress Series, 73, 295305. DOI: 10.3354/meps073295

Bergeron, J.P. (1997). Nucleic acids in ichthyoplankton ecology: a review, with emphasis on recent advances for new perspectives. Journal of Fish Biology, 51, 284-302. https://doi.org/10.1111/j.1095-8649.1997.tb06104.x

Bjornsson, B.T. (1997). The biology of salmon growth hormone: from daylight to dominance. Fish Physiology and Biochemistry, 17(1-6),9-24. https://doi.org/10.1023/A:1007712413908

Boyd, C.E. 1999. Water Quality: An Introduction. Kluwer Academic Publishers Group, The Netherlands. 330 pp.

Carvalho, A.P., Araújo, L., \& Santos, M.M. (2006). Rearing zebrafish (Danio rerio) larvae without live food: evaluation of a commercial, a practical and a purified starter diet on larval performance. Aquaculture Research, 37(11), 1107-1111. https://doi.org/10.1111/j.1365 2109.2006.01534.x

Chen, T.T., Marsh, A., Shamblott, M., Chan, K.M., Tang, Y.L., Cheng, C.M., \& Yang, B.Y. (1994). 6 structure and evolution of fish growth hormone and insulinlike growth factor genes. In Fish physiology (Vol. 13, pp. 179-209). Academic Press. https://dx.doi.org/10.1073\%2Fpnas.94.5.2068

Clemmesen, C. (1994). The effect of food availability, age or size on the RNA/DNA ratio of individually measured herring larvae: laboratory calibration. Marine Biology, 118(3), 377- 382. https://doi.org/10.1007/BF00350294

Devlin, R.H., Biagi, C.A., \& Yesaki, T.Y. (2004). Growth, viability and genetic characteristics of $\mathrm{GH}$ transgenic coho salmon strains. Aquaculture, 236(1-4), 607-632. https://doi.org/10.1111/jfb.13233

Drew, R.E., Rodnick, K.J., Settles, M., Wacyk, J., Churchill, E., Powell, M.S., \& Robison, B.D. (2008). Effect of starvation on transcriptomes of brain and liver in adult female zebrafish (Danio rerio). Physiological genomics, 35(3), 283-295. DOI: 10.1152/physiolgenomics.90213.2008

Engeszer, R.E., Patterson, L.B., Rao, A.A., \& Parichy, D.M. (2007). Zebrafish in the wild: a review of natural history and new notes from the field. Zebrafish, 4(1), 21-40. DOI: 10.1089/zeb.2006.9997

Foley, C.J., Bradley, D.L., \& Hook, T.O. (2016). A review and assessment of the potential use of RNA: DNA ratios to assess the condition of entrained fish larvae. Ecological Indicators, 60, 346-357.

https://doi.org/10.1016/j.ecolind.2015.07.005

Gonzales, J., \& John, M. (2012). Preliminary evaluation on the effects of feeds on the growth and early reproductive performance of zebrafish (Danio rerio). Journal of the American Association for Laboratory Animal Science, 51(4), 412-417.

Gorokhova, E. (2003). Relationships between nucleic acid levels and egg production rates in Acartia bifilosa: implications for growth assessment of copepods in situ. Marine Ecology Progress Series, 262, 163-172. DOI: 10.3354/meps262163

Gorokhova, E., \& Kyle, M. (2002). Analysis of nucleic acids in Daphnia: development of methods and ontogenetic variations in RNA-DNA content. Journal of Plankton Research, 24(5), 511-522.

https://doi.org/10.1093/plankt/24.5.511
Gwak, W.S., Tanaka, Y., Tominaga, O., Tsusaki, T., \& Tanaka, M. (2003). Field evaluation by RNA/DNA ratios on postrelease nutritional status of released and wild Japanese flounder Paralichthys olivaceus juveniles. Journal of Experimental Marine Biology and Ecology, 293(1), 107124.

Kaushik, S., Georga, I., \& Koumoundouros, G. (2011). Growth and body composition of zebrafish (Danio rerio) larvae fed a compound feed from first feeding onward: toward implications on nutrient requirements. Zebrafish, 8(2), 87-95.

https://doi.org/10.1089/zeb.2011.0696

Lawrence, C. (2007). The husbandry of zebrafish (Danio rerio): a review. Aquaculture, 269(14), 1-20. http://dx.doi.org/10.1016/j.aquaculture.2007.04.077

Lieschke, G.J., \& Currie, P.D. (2007). Animal models of human disease: zebrafish swim into view. Nature Reviews Genetics, 8(5), 353. https://doi.org/10.1038/nrg2091

Matthews, M., Trevarrow, B., \& Matthews, J. (2002). A virtual tour of the guide for zebrafish users. Resource, 31, 3440. https://doi.org/10.1038/5000140

Moriyama, S., Ayson, F.G., \& Kawauchi, H. (2000). Growth regulation by insulin-like growth factor-I in fish. Bioscience, biotechnology, and biochemistry, 64(8), 1553-1562. https://doi.org/10.1271/bbb.64.1553

Panserat, S., Plagnes-Juan, E., \& Kaushik, S. (2001). Nutritional regulation and tissue specificity of gene expression for proteins involved in hepatic glucose metabolism in rainbow trout (Oncorhynchus mykiss). Journal of Experimental Biology, 204(13), 2351-2360.

Panserat, S., \& Kaushik, S.J. (2010). Regulation of gene expression by nutritional factors in fish. Aquaculture Research, 41(5), 751-762.

https://doi.org/10.1111/j.1365-2109.2009.02173.x

Pepin, P., Evans, G.T., \& Shears, T.H. (1999). Patterns of RNA/DNA ratios in larval fish and their relationship to survival in the field. ICES Journal of Marine Science, 56(5), 697- 706.

https://doi.org/10.1006/jmsc.1999.0496

Perez-Sanchez, J., Calduch-Giner, J.A., Mingarro, M., de Celis, S.V.R., Gómez-Requeni, P., Saera-Vila, A., \& Valdivia, M.M. (2002). Overview of fish growth hormone family. New insights in genomic organization and heterogeneity of growth hormone receptors. Fish Physiology and Biochemistry, 27(3-4), 243-258.

Pfaffl, M.W., Horgan, G.W., \& Dempfle, L. (2002). Relative expression software tool (RESTC) for group-wise comparison and statistical analysis of relative expression results in real-time PCR. Nucleic acids research, 30(9), e36-e36.

Pompa, T.J., \& Masser, M. (1999). Tilapia, life history and biology Southern Regional Aquaculture Center (SRAC) Publication, No. 283. United States Department of Agriculture, Cooperative States Research, Education and Extension Service. p. 4.

Rabbane, M.G., Rahman, M.R. (2017). Effects of natural and commercial diets on growth, reproductive performances and embryogenesis of zebrafish Danio rerio. Dhaka University Journal of Biological Science, 26(2), 159-166.

Radaelli, G., Domeneghini, C., Arrighi, S., Bosi, G., Patruno, M., \& Funkenstein, B. (2003). Localization of IGF-I, IGF-I receptor, and IGFBP-2 in developing Umbrina cirrosa (Pisces: Osteichthyes). General and comparative endocrinology, 130(3), 232-244. https://doi.org/10.1016/S0016-6480(02)00609-3 
Rahman, M.A., Bhadra, A., Begum, N., \& Hussain, M.G. (1997). Effects of some selective supplemental feeds on the survival and growth of catfish (Clarias batrachus Lin.) fry. Bangladesh Journal of Fisheries Research, 1(2), 5558.

Regnault, M., \& Luquet, P. (1974). Study by evolution of nucleic acid content of prepuberal growth in the shrimp Crangon vulgaris. Marine Biology, 25(4), 291-298. https://doi.org/10.1007/BF00404971

Reinecke, M., Bjornsson, B.T., Dickhoff, W.W., McCormick, S.D., Navarro, I., Power, D.M., \& Gutiérrez, J. (2005). Growth hormone and insulin-like growth factors in fish: where we are and where to go. General and comparative endocrinology, 142(1-2), 20-24.

https://doi.org/10.1016/j.ygcen.2005.01.016

Ribas, L., \& Piferrer, F. (2014). The zebrafish (Danio rerio) as a model organism, with emphasis on applications for finfish aquaculture research. Reviews in Aquaculture, 6(4), 209- 240. https://dx.doi.org/10.3389\%2Ffgene.2014.00313

Robison, B.D., Drew, R.E., Murdoch, G.K., Powell, M., Rodnick, K.J., Settles, M., \& Lewis, S.S. (2008). Sexual dimorphism in hepatic gene expression and the response to dietary carbohydrate manipulation in the zebrafish (Danio rerio). Comparative Biochemistry and Physiology Part $D$ : Genomics and Proteomics, 3(2), 141-154.

Smith, T.R., \& Buckley, L.J. (2003). RNA-DNA ratio in scales from juvenile cod provides a nonlethal measure of feeding condition. Transactions of the American Fisheries Society, 132(1), 9-17.

Timmons, M.B., Ebeling, J.M., Wheaton, F.W., Summerfelt,
S.T., \& Vinci, B.J. (2002). Recirculating Aquaculture Systems, 2nd Editions. Cayuga Aqua Ventures, LLC., Ithaca, NY, 760. https://doi.org/10.1071/MF9960301

Ulloa, P.E., Iturra, P., Neira, R., \& Araneda, C. (2011). Zebrafish as a model organism for nutrition and growth: towards comparative studies of nutritional genomics applied to aquacultured fishes. Reviews in Fish Biology and Fisheries, 21(4), 649-666. DOI: 10.1007/s11160-0119203-0

Ulloa, P.E., Pena, A.A., Lizama, C.D., Araneda, C., Iturra, P., Neira, R., \& Medrano, J.F. (2013). Growth response and expression of muscle growth-related candidate genes in adult zebrafish fed plant and fishmeal protein-based diets. Zebrafish, 10(1), 99-109.

https://doi.org/10.1089/zeb.2012.0823

Westerfield, M. (1995). The zebrafish book: a guide for the laboratory use of zebrafish (Brachydanio rerio). University of Oregon press, Eugene, OR. 385 pp.

Yang, B.Y., Chan, K.M., Lin, C.M., \& Chen, T.T. (1997). Characterization of rainbow trout (Oncorhynchus mykiss) growth hormone 1 gene and the promoter region of growth hormone 2 gene. Archives of biochemistry and biophysics, 340(2), 359-368. https://doi.org/10.1111/j.1095-8649.2001.tb00168.x

Zehra, S., \& Khan, M.A. (2013). Dietary lysine requirement of fingerling Catla catla (Hamilton) based on growth, protein deposition, lysine retention efficiency, RNA/DNA ratio and carcass composition. Fish physiology and biochemistry, 39(3), 503- 512.

https://doi.org/10.1007/s10695-012-9715-0 